\title{
Paracoccidioides brasiliensis habitat: far beyond armadillo burrows?
}

\author{
Priscila Marques de Macedo ${ }^{+}$, Bruno de Souza Scramignon-Costa, Rodrigo Almeida-Paes, \\ Luciana Trilles, Larissa Siston Cosendey de Oliveira, Rosely Maria Zancopé-Oliveira, \\ Antonio Carlos Francesconi do Valle, Bodo Wanke
}

Fundação Oswaldo Cruz-Fiocruz, Instituto Nacional de Infectologia Evandro Chagas, Rio de Janeiro, RJ, Brasil

Paracoccidioides spp. isolation from environmental samples is rare and hardly reproducible. Molecular techniques have facilitated the fungal detection. However, it can be still difficult. Some strategies to enhance the capacity of DNA detection have been adopted, including the analysis of soil samples belonging to the habitat of animals from which Paracoccidioides spp. have already been isolated, notably armadillo burrows. To date, the detection of Paracoccidioides spp. has not yet been reported from outbreak hotspots. Clusters and outbreaks of acute paracoccidioidomycosis (PCM), usually a more severe clinical form, have currently occurred in urban areas being associated to climate changes, deforestation, and great constructions. These occurrences potentially signalise the fungus' environmental niche, a riddle not yet solved. The authors performed an environmental investigation in a deeply disturbed area, after a highway construction in Rio de Janeiro, Brazil, where a recent outbreak of acute PCM occurred. Specific DNA sequences of Paracoccidioides brasiliensis were detected in shallow soil samples around the highway, reinforcing the association between the road construction and this PCM outbreak.

Key words: outbreak - environment - paracoccidioidomycosis - Paracoccidioides brasiliensis

Acute forms of paracoccidioidomycosis (PCM), a systemic mycosis caused by inhalation of Paracoccidioides spp. conidia present in soil from endemic areas, are usually more severe and less common than the chronic PCM form. ${ }^{(1)}$ In 2017 we reported an outbreak of acute PCM after a highway construction in Rio de Janeiro, Brazil, involving eight young patients and characterised by severe clinical presentations, complications, and one death. ${ }^{(2)}$ After this outbreak, 18 additional cases of acute PCM were diagnosed in the same study area, a rate 4.3 times higher than that expected for this period. Considering the outbreak, the road construction, the ongoing diagnosis of new cases of acute PCM, and the knowledge that the fungus lives in soil, the authors performed an environmental investigation along the roadside to reinforce the hypothesis that the outbreak was related to the road construction.

We collected soil samples (around $100 \mathrm{~g}$ each) in the surroundings of the roadside (no more than $300 \mathrm{~m}$ away). Nine samples were obtained nearby the epicenter of the cases' occurrence (Nova Iguaçu municipality, 12 $\mathrm{km}$ away from the residence of one patient previously described), and nine soil samples at Seropédica, another municipality where a severe acute PCM case recently occurred ( $8 \mathrm{~km}$ away from the residence of this patient). Table depicts the GPS coordinates, dates, seasons, and

doi: 10.1590/0074-02760200208

Financial support: INI/Fiocruz (Programa Jovens Pesquisadores).

+Corresponding author: priscila.marques@ini.fiocruz.br

(1) https://orcid.org/0000-0002-6900-9703

Received 04 May 2020

Accepted 08 July 2020 climatic conditions of the environmental investigations. Soil samples were processed for culture and DNA extraction within $24 \mathrm{~h}$ after field work. For culture, $1 \mathrm{~g}$ of each soil sample was diluted in $9 \mathrm{~mL}$ sterile saline, vortexed for $10 \mathrm{~min}$ and heavy particles were allowed to settle down for $5 \mathrm{~min}$. Serial tenfold dilutions of the upper homogenous suspensions were plated on Mycosel Agar (Difco, Sparks, MD, USA) at $25^{\circ} \mathrm{C}$ for 60 days. DNA extraction was conducted using the DNeasy ${ }^{\circledR}$ PowerSoil $®$ Kit (Qiagen, Hilden, Germany). Molecular analyses through nested-polymerase chain reaction (PCR) were performed as described. ${ }^{(3)}$ The following controls were used: (1) soil artificially seeded with Paracoccidioides brasiliensis (positive control), following the protocols published by Theodoro et al.;(3) (2) P. brasiliensis $\mathrm{Pb} 18$ strain (another positive control); (3) beach sand from Barra da Tijuca, Rio de Janeiro (negative control); (4) all PCR reagents without any DNA template (internal negative control). Cultures did not yield colonies of $P$. brasiliensis, however, the presence of specific DNA sequences of $P$. brasiliensis was detected in both sites studied: two soil samples from Seropédica, and one soil sample from Nova Iguaçu (Figure). DNA bands from the nested-PCR were excised from the gel, purified with the illustra $^{\mathrm{TM}} \mathrm{GFX}^{\mathrm{TM}}$ PCR DNA and Gel Band Purification Kit (GE Healthcare, Buckinghamshire, UK), sequenced at the sequencing platform at Oswaldo Cruz Foundation - PDTIS/Fiocruz, and P. brasiliensis was revealed as best hit in all three positive samples after BLAST search (sequence numbers MT726207 to MT726209).

Paracoccidioides spp. isolation from soil samples is a great challenge. This pathogen is fastidious in culture and lives in tropical areas where the high fungal diversity and concentration in soil may inhibit its growth and isolation. Some other hypotheses raised in the literature consider a more selective microniche, a transitory and short saprobic phase, or a possible obligatory parasite phase in wild animals supported by the high frequency 
TABLE

GPS coordinates, dates, seasons, and climatic conditions of the environmental investigations

\begin{tabular}{|c|c|c|c|c|c|c|}
\hline \multirow[b]{2}{*}{ Place } & \multirow[b]{2}{*}{ GPS } & \multirow[b]{2}{*}{ Date } & \multirow[b]{2}{*}{ Season } & \multirow[b]{2}{*}{ Temperature } & \multicolumn{2}{|c|}{ Last rainfall } \\
\hline & & & & & Date & Precipitation \\
\hline Seropédica & $\begin{array}{l}\text { S } 22^{\circ} 46^{\prime} 52.3^{\prime \prime}, \\
\text { W } 043^{\circ} 45^{\prime} 27.1^{\prime \prime}\end{array}$ & $07 / 12 / 2019$ & Winter & $26^{\circ} \mathrm{C}-14^{\circ} \mathrm{C}$ & 8 days before & $2.0 \mathrm{~mm}$ \\
\hline Nova Iguaçu & $\begin{array}{c}\text { S 22040'37.3"', } \\
\text { W } 043^{\circ} 24^{\prime} 17.7^{\prime \prime}\end{array}$ & $03 / 16 / 2020$ & Summer & $34^{\circ} \mathrm{C}-24^{\circ} \mathrm{C}$ & 12 days before & $2.0 \mathrm{~mm}$ \\
\hline
\end{tabular}
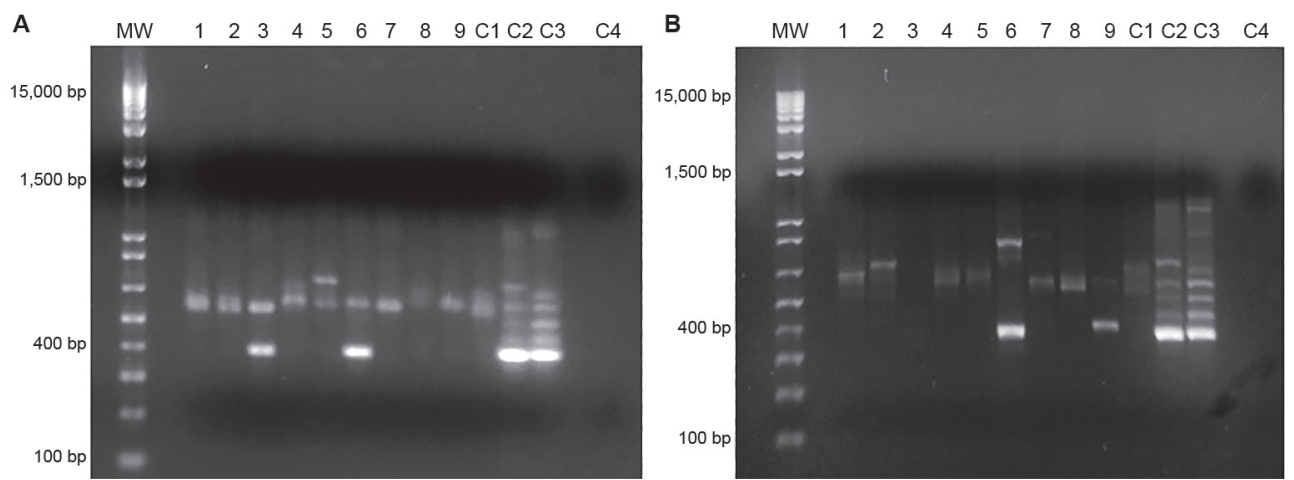

Nested polymerase chain reaction (PCR) results, with specific Paracoccidioides brasiliensis ITS primers, of DNA extracted from soil samples of: (A) Seropédica, and (B) Nova Iguaçu municipalities. MW: 1 kb plus DNA Ladder (Invitrogen); Lanes 1 to 9: soil samples from each site; C1: negative soil control (beach sand); C2: positive soil control; C3: Pb18 strain; C4: negative internal control.

of infected armadillos in some endemic areas. ${ }^{(4)}$ Molecular techniques have facilitated the detection of Paracoccidioides spp. in environmental samples. However, this detection can be still difficult as it was postulated a low sporulation capacity and a very low inoculum level of this fungal agent in soil. ${ }^{(4,5)}$ In this context, some strategies to enhance the capacity of DNA detection have been adopted: the DNA extraction in triplicate from each soil sample, including a final step of concentration; the nested PCR due to its higher capacity of DNA amplification; and the analysis of soil samples collected from the habitat of animals from which Paracoccidioides spp. have already been isolated.(6) Our work was developed in a deeply disturbed area, the samples were collected in the roadside, $10 \mathrm{~cm}$ of soil depth, and DNA extraction was performed once from each sample. The two sites where samples were collected had positive results, suggesting that the environmental disruption related to the road construction was responsible for a greater exposure of infective Paracoccidioides spp. propagules and, consequently, to the reported PCM outbreak.

The One Health concept (WHO, 2017) recognises the connection between people, animals, and the environment, encouraging scientists to investigate human's role in the emergency of diseases due to an imbalance in this connection. ${ }^{(7)}$ To date, reports warn about alterations in PCM epidemiology related to climate and rainfall pattern changes, as well as other environmental human disruptions such as deforestation and big constructions, causing more severe PCM clinical profiles in urban areas. ${ }^{(2,8,9)}$ Traditionally, PCM is characterised by a long period of latency, absence of reported outbreaks, and paucity of acute cases as well as confirmed subclinical infections, which historically tended to hinder determination of the possible sources of infection. ${ }^{(10)}$

The findings herein reported reinforce our original hypothesis of association between the road construction and the PCM outbreak in Rio de Janeiro, Brazil, opening up new perspectives to other possible environmental sources of PCM infection.

\section{AUTHORS' CONTRIBUTION}

PMM - Project coordination; PMM, BSSC, LT and BW - field work; BSSC and LSCO - performed the experiments; RAP, LT and RMZO - experiments supervision; PMM, RAP, LT, BW, RMZO and ACFV - formal analysis; PMM, RAP, LT, $\mathrm{BW}, \mathrm{RMZO}$ and ACFV - writing (original draft preparation); PMM and RAP - writing (review and editing); PMM - funding acquisition. All authors read and approved the manuscript.

\section{REFERENCES}

1. Shikanai-Yasuda MA, Mendes RP, Colombo AL, Queiroz-Telles F, Kono ASG, Paniago AMM, et al. Brazilian guidelines for the clinical management of paracoccidioidomycosis. Rev Soc Bras Med Trop. 2017; 50(5): 715-40.

2. Valle ACF, de Macedo PM, Almeida-Paes R, Romão AR, Lazéra MS, Wanke B. Paracoccidioidomycosis after highway construction, Rio de Janeiro, Brazil. Emerg Infect Dis. 2017; 23(11): 1917-19. 
3. Theodoro RC, Candeias JM, Araújo Jr JP, Bosco SM, Macoris SA, Padula LO, et al. Molecular detection of Paracoccidioides brasiliensis in soil. Med Mycol. 2005; 43(8): 725-9.

4. Franco M, Bagagli E, Scapolio S, Lacaz CDS. A critical analysis of isolation of Paracoccidioides brasiliensis from soil. Med Mycol. 2000; 38(3): 185-91.

5. Mendes JF, Von Groll A, Poester VR, Brasil CL, Brandolt TM, Klafke GB, et al. Paracoccidioides spp. in soil from the Pampa Biome in southern Brazil. Curr Microbiol. 2019; 76(2): 258-62.

6. Arantes TD, Theodoro RC, Teixeira MM, Bosco SM, Bagagli E. Environmental mapping of Paracoccidioides spp. in Brazil reveals new clues into genetic diversity, biogeography and wild host association. PLoS Negl Trop Dis. 2016; 10(4): e0004606.
7. WHO - World Health Organization. 2017. Available from: https:// www.who.int/features/qa/one-health/en/.

8. Barrozo LV, Benard G, Silva ME, Bagagli E, Marques SA, Mendes RP. First description of a cluster of acute/subacute paracoccidioidomycosis cases and its association with a climatic anomaly. PLoS Negl Trop Dis. 2010; 4(3): e643.

9. Giusiano G, Aguirre C, Vratnica C, Rojas F, Corallo T, Cattana $\mathrm{ME}$, et al. Emergence of acute /subacute infant juvenile paracoccidioidomycosis in northeast Argentina: effect of climatic and anthropogenic changes? Med Mycol. 2019; 57(1): 30-7.

10. Restrepo A, McEwen JG, Castañeda E. The habitat of Paracoccidioides brasiliensis: how far from solving the riddle? Med Mycol. 2001; 39(3): 233-41. 